Vol. 4, No. 1, 2018

Iryna Dolinska ${ }^{1}$, Roman Palash ${ }^{2}$

${ }^{1}$ Department of Acoustic Methods of Technical Diagnostics, Karpenko Physico-Mechanical Institute of the NAS of Ukraine, 5, Naukova Str., Lviv, Ukraine, E-mail: ira_dolinska@ukr.net

${ }^{2}$ Department of Welding Manufacture, Diagnostics and Restoration of Metal Structures, Lviv Polytechnic National University, 12, S. Bandera Str., Lviv, Ukraine, E-mail: rpalash@yahoo.com

\title{
METHOD FOR CALCULATING THE OPERATING LIFE OF A STEAM PIPE WITH A CREEP-FATIGUE CRACK NEAR A WELD JOINT
}

Received: October 23, 2017 / Revised: February 15, 2018 / Accepted: June 26, 2018

(C) Dolinska I., Palash R., 2018

Abstract. A method for determining the period of sub-critical growth of a semielliptical creep-fatigue crack in the internal surface of a pipe wall of the steam pipeline is proposed. The crack is located near the ring weld in the field of residual stresses in the heat-affected zone. The dependence of the residual resource of the pipe of a steam pipeline with the weld joint on the location of the centre of the crack relative to the axis of the weld is ascertained.

Keywords: welded joint, steam pipeline, creep-fatigue crack, residual resource, period of subcritical growth of the crack.

\section{Introduction and problem statement}

The development of the defects of different origin (metallurgical, construction-and-assembling etc.) in the steam pipelines causes their operational failures or, sometimes, breakdowns, which lead not only to considerable material losses, but to environmental damage as well. Therefore, providing reliability and safety of the operation of the steam pipelines being determining requirement during their operation over a necessary time period and under the influence of different physical agents is one of the most important scientific and technical problems.

So, nowadays, significant tasks in the field are the diagnostics of damages of the pipe walls of steam pipelines, the analysis of their load conditions and, on this basis, prediction of their residual resource, which will enable predicting and preventing the emergency. For this, many investigations have been carried out for the base material of the pipe without taking into account the influence of welds. The presence of welds complicates the calculations of pipeline operating life. It is caused either by heterogeneity of the material, or by residual stresses [1-3].

In this work, the method for the calculation of residual resource of the pipe of the steam pipeline with a creep-fatigue crack near the weld joint under the cyclic load and high-temperature creep is proposed.

\section{Peculiarities of calculating weld joints of steam pipelines}

The process of the destruction of welded constructions is determined by several factors. The most crucial influence is caused by the heterogeneity of mechanical properties of material in the welding zone, high residual stresses and defective structure of welds and surrounding zones.

The prediction of operating life of weld joints of steam pipelines includes [4] the complex of essential methods for resource estimation taking into account the peculiarities of structure changes and metal properties, in particular:

- includes the computational and structural methods of evaluating the operating life of weld joints;

- takes into account the results of statistical analysis of operational damages of weld joints of different dimension types;

- takes into account the patterns of structure changes and properties of metal of the zones in general and weld joints in particular during their operating life;

- takes into account the features of operational conditions of steam pipelines. 
The reliability of weld joints of steam pipelines operating under the conditions of creep at the longterm time-variable load can be depicted as a diagram of failures over some time period divided into three stages (Fig. 1) [4]:

1) the primary stage of operation with operation time to 20 thousand hours, during which the largest number of failures occur (for example, in chrome-molibdenum-vanadium steels). The damage develops due to the phenomena of cold brittleness and creep under the conditions of dispersive metal embrittlement and is mainly caused by breakdowns in the regular thermal welding process: not fulfilling optimal thermal welding conditions (undersupply or unreasonable cancellation of thermal treatment); using electrodes without re-calcination and metal joints without proper cleaning;

2) further continual operation stage with operating time more than 100,000 hours, without (or minimal) damage of weld joints. This stage is considered as a rather trouble-free period of continual operation of weld joints;

3) final stage of operation, when the number of damages of weld joints gradually increases to a great extent due to metallic wear (degradation of microstructure, microdamage of metal and, in consequence, decrease in high-temperature strength of weld joints.

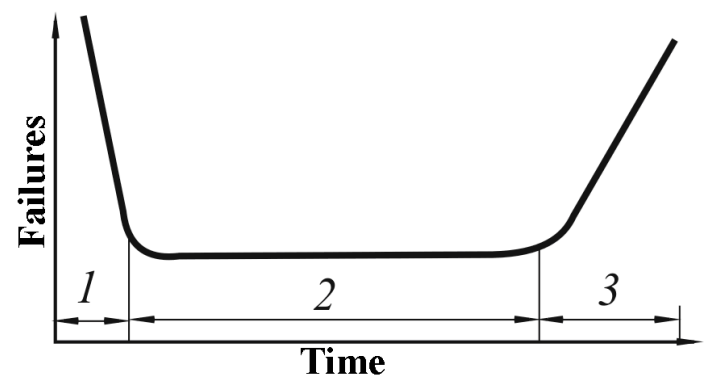

Fig. 1. Graph of reliability

of weld joints operating under the creep conditions

Therefore, while solving tasks of weld joint diagnosis and the prediction of their operation life for its extending, the use of state-of-the-art calculating, structural and statistical methods for the evaluation of the reliability of weld joints of steam pipelines is considered to be important and essential.

\section{Residual life of an infinite plate with a rectilinear weld joint and a small crack}

Let us consider the infinite metal plate with a weld joint (Fig. 2). The plate is weakened by the crack of initial length of $l_{0}$ located at the distance of $x_{1}$ from the weld joint. It is assumed that the plate is heated to the high temperature $T_{0}\left(T_{0}>0,3 T_{p}, T_{p}\right.$ is melting temperature of object material), which causes high-temperature creep in the pre-damage zone, and is spread in the infinitely distant points by the homogeneously distributed forces with the intensity $p$, which are cyclically changing with a retention $T$ in the period and are directed normally to the line of crack location. The task consists in determining the number of loading periods $N=N_{\mathrm{S}}$, after approaching which, the crack grows to the critical dimension $l=l_{*}$ and the plate is destroyed.

This task will be solved in a following way. Basing on the energy method proposed in $[5,6]$, let us write down the equation for determining the kinetics of spreading the creep-fatigue crack in the thin-walled construction elements in the following form

$$
\begin{aligned}
& \frac{d l}{d N}=\frac{0,25 \alpha_{0}(1-R)^{4}}{\sigma_{0 f} E\left(K_{f C}^{2}-K_{I \max }^{2}\right)}\left\{\left[K_{\operatorname{Imax}}^{2}(l)+A_{2}\left[K_{\operatorname{Imax}}^{2}(l) K_{f C}^{-2}\right]^{m} \ln \left(\frac{t_{0}+T}{t_{1}}\right)\right]^{2}-\right. \\
& \left.-\left[\left[K_{t h}^{2}+A_{2}\left[K_{t h}^{2} K_{f C}^{-2}\right]^{m} \ln \left(\frac{t_{0}+T}{t_{1}}\right)\right]^{2}\right]\right\},
\end{aligned}
$$

where $l$ is the length of the crack; $N$ is the number of loading periods; $A_{2}=A_{1} t_{0} \sigma_{0 f} E ; A_{1}, m, t_{1}$ are the characteristics of material creep determined at the experiment; $\sigma_{0 f}$ are averaged stresses in the pre- 
damage zone; $T$ is a retention in the period; $\alpha_{0}$ is a constant determined experimentally; $E$ is a coefficient of elasticity; $R$ is a coefficient of the asymmetry of a load period; $K_{\text {Imax }}$ is a maximum value of the coefficient of stress intensity $K_{\mathrm{I}}$ in the period; $K_{f C}$ is a critical value of $K_{\mathrm{I}}$ at periodical loading; $K_{t h}$ is a lower threshold value of $K_{\mathrm{I}}$, at which creep-fatigue damaging does not occur; $t_{0}=1$ hour.

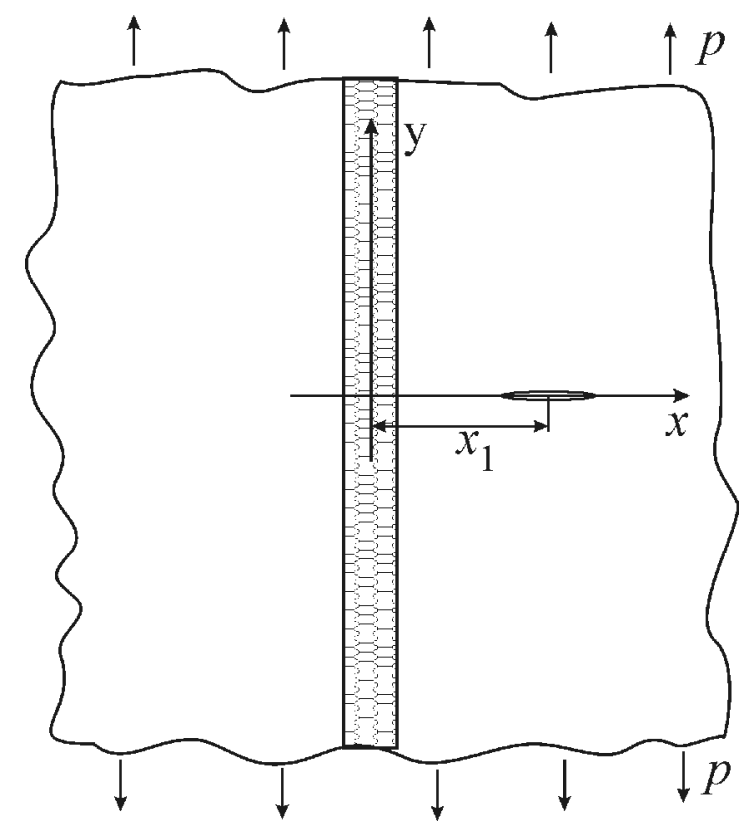

Fig. 2. Diagram of loading the plate with a weld joint and a small crack

For evaluating the period of pre-critical growth of the crack in the plate (residual resource), let us add starting condition (2) and finite condition (3) to equation (1)

$$
\begin{array}{cl}
N=0, & l(0)=l_{0} ; \\
N=N_{S}, & l\left(N_{S}\right)=l_{*} .
\end{array}
$$

Critical length $l_{*}$ of the crack is here determined by the Irwin criterion [7]:

$$
K_{\mathrm{I}}\left(l_{*}\right)=K_{f C} .
$$

Therefore, at known material characteristics $A_{1}, m, t_{1}, \sigma_{0 f}, K_{f C}, K_{t h}, \alpha_{0}$, the period of precritical growth of the creep-fatigue crack can be determined by the computational model (1)-(3).

Residual stress in the welded plate is determined on the basis of Machnenko's research [7] as follows:

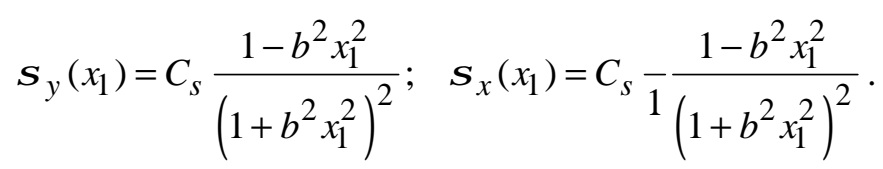

In diagram form the distribution of residual stresses in the welded plate (steel 09G2S) is shown in Fig. 3 [7]. Unknown parameters $C_{s}, b$ are determined using the experimental data.

For the simplification of computations it is assumed that the crack is small in comparison to the width of the distribution of residual stresses, and when it approaches to the weld joint the averaged values of residual stresses can be used evenly along the crack length.

In this case, the coefficient of stress intensity $K_{\text {Imax }}$ is determined by the formula [8]

$$
K_{\operatorname{Imax}}=\left(\sigma_{y}\left(x_{1}\right)+p\right) \sqrt{\pi l} .
$$




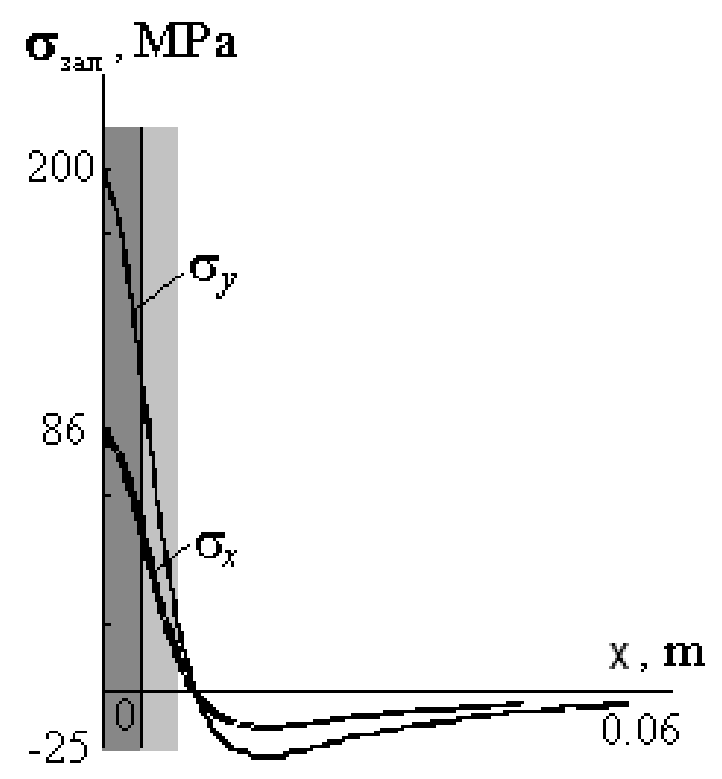

Fig. 3. Distribution of longitudinal $\left(\sigma_{y}\right)$ and lateral $\left(\sigma_{x}\right)$ residual stresses in the welded plate

Taking into account (5), the computational model (1)-(3) will take the following form

$$
\frac{d l}{d N}=\frac{0,25 \alpha_{0}(1-R)^{4}}{\sigma_{0 f} E\left(K_{f C}^{2}-\left(\sigma_{y}\left(x_{1}\right)+p\right)^{2} \pi l\right)}\left\{\begin{array}{c}
{\left[\begin{array}{c}
\left(\sigma_{y}\left(x_{1}\right)+p\right)^{2} \pi l+ \\
+
\end{array} A_{2}\left[\left(\sigma_{y}\left(x_{1}\right)+p\right)^{2} \pi l K_{f C}^{-2}\right]^{m} \ln \left(\frac{t_{0}+T}{t_{1}}\right)\right]^{2}-} \\
-\left[\left[K_{t h}^{2}+A_{2}\left[K_{t h}^{2} K_{f C}^{-2}\right]^{m} \ln \left(\frac{t_{0}+T}{t_{1}}\right)\right]^{2}\right]
\end{array}\right\}
$$

under the initial condition

$$
N=0, \quad l(0)=l_{0}
$$

and finite condition

$$
N=N_{s}, \quad l\left(N_{s}\right)=\pi^{-1}\left(\sigma_{y}\left(x_{1}\right)+p\right)^{-2} K_{f C}^{2} .
$$

After equation (7) being integrated under the conditions (8), (9), the formula for determining the residual resource of the plate is obtained

$$
\begin{aligned}
N_{s}= & \frac{4 \sigma_{o f} E}{\alpha_{0}(1-R)^{4}} \int_{l_{0}}^{l_{*}}\left\{\left[\left(\sigma_{y}\left(x_{1}\right)+p\right)^{2} \pi l+A_{2}\left[\left(\sigma_{y}\left(x_{1}\right)+p\right) \pi l / K_{f C}^{2}\right]^{m} \ln \left(\frac{t_{0}+T}{t_{1}}\right)\right]^{2}-\right. \\
& \left.-\left[K_{t h}^{2}+A_{2}\left[K_{t h}^{2} / K_{f C}^{2}\right]^{m} \ln \left(\frac{t_{0}+T}{t_{1}}\right)\right]^{2}\right\}^{-1} \cdot\left(K_{f C}^{2}-\left(\sigma_{y}\left(x_{1}\right)+p\right)^{2} \pi l\right) d l .
\end{aligned}
$$

For computing the task, let us consider the example of the plate made of steel 09G2S, loaded by the cyclic stresses with the magnitude of $p=100 \mathrm{MPa}\left(T_{0}=300{ }^{\circ} \mathrm{C}\right)$ at the initial crack length of $2 \mathrm{~mm}$. The material characteristics are chosen according to the results of investigations in [7, 9, 10]: $K_{f C}=70 \mathrm{MPa} \sqrt{\mathrm{m}}, \quad K_{t h}=9.3 \mathrm{MPa} \sqrt{\mathrm{m}}, \quad R=0, \quad T=12 \mathrm{~h}, \quad \alpha_{0}=1.1, \quad C_{s}=200, \quad b=144.45$, $A_{1}=3.12 \cdot 10^{-3}$ meters per hour, $m=0.8, t_{1}=0.015 \mathrm{~h}, \sigma_{0 f}=220 \mathrm{MPa}, \quad E=1.9 \cdot 10^{5} \mathrm{MPa}$. By the 
substitution of these values in correlation (10), the dependence of the residual resource of the plate $N_{S}$ on the distance from a crack centre to the weld joint axis (Fig. 4).

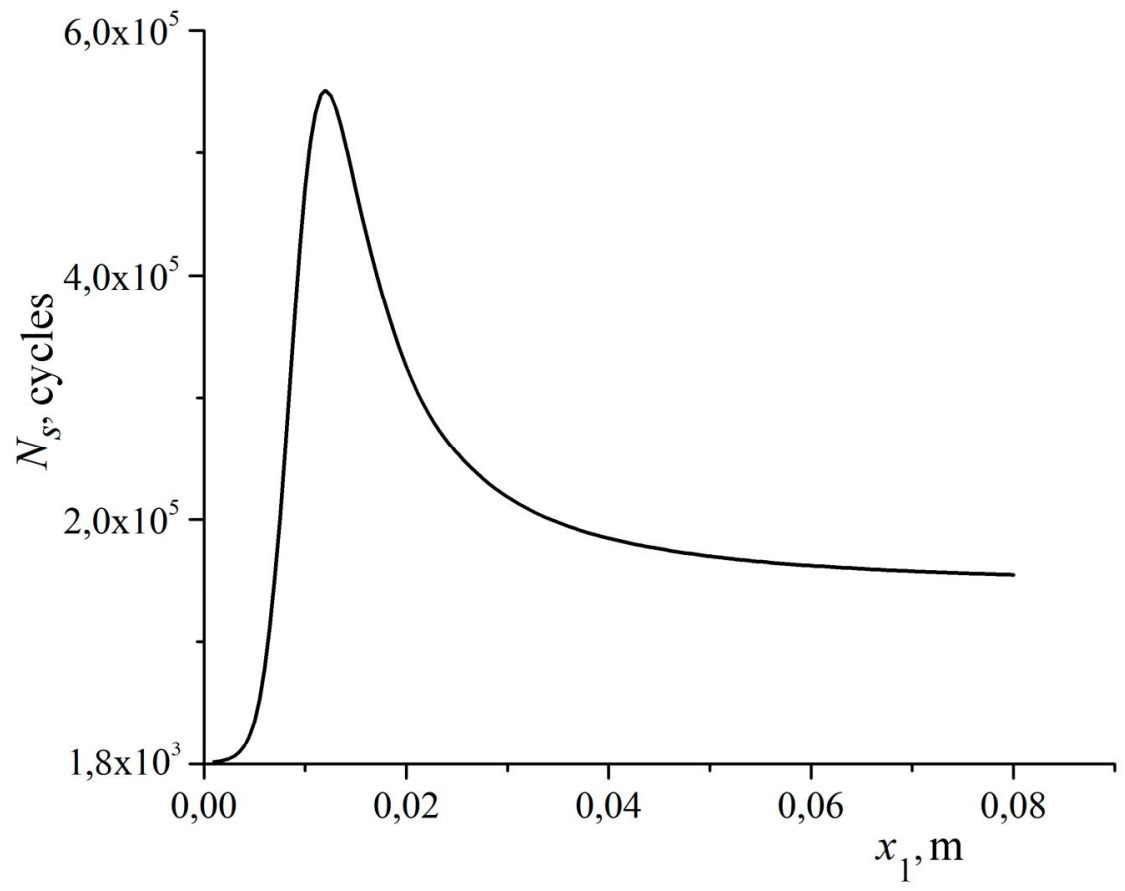

Fig. 4. Dependence of the residual resource of the plate $N_{s}$ on the distance $x_{1}$ from a crack centre to the weld joint axis

As it can be seen, residual stresses affect the residual resource of the plate in an ambiguous way. The longest residual resource of the plate can be achieved under the influence of compression residual stresses.

\section{Determining the period of pre-critical growth of the creep-fatigue crack in the steam pipe line near the ring weld joint}

Let us consider the pipe of the steam pipeline weakened by the inside surface semi-elliptic crack with semi-axes $a, b$, located near the weld joint (Fig. 5). In Fig. 5, $h$ is a thickness of the pipeline wall; $r$ is a radius of the pipe of the steam pipeline; $x_{1}$ is a distance from the crack centre to the axis of the weld joint. It can be assumed that in the steam pipeline turning on and off the pressure can occur due to some technological conditions. Therefore, loading the steam pipe line by pressure $p$ will be roughly cyclic with some retention in the period. Under such loading conditions the creep-fatigue crack will develop in the steam pipeline. For finding the pre-critical period of the growth of the creep-fatigue crack in the steam pipeline near the ring weld joint (time before dehermetization), the computational model of the development of such a defect is created and time of its invasion through the wall of the pipe (Fig. 5) has been created.

On the basis of the developed energy method [5,6], kinetics of the spread of the creep-fatigue crack is determined by a differential equation

$$
\begin{gathered}
\frac{d S}{d N}=\frac{\alpha_{0}(1-R)^{4}}{4 \sigma_{0 f} E\left(K_{f C}^{2}-K_{I \max }^{2}\right)}\left\{\left[K_{I \max }^{2}+A_{2}\left[K_{\operatorname{Imax}}^{2} K_{f C}^{-2}\right]^{m} \ln \left(\frac{t_{0}+T}{t_{1}}\right)\right]^{2}-\right. \\
\left.-\left[\left[K_{t h}^{2}+A_{2}\left[K_{t h}^{2} K_{f C}^{-2}\right]^{m} \ln \left(\frac{t_{0}+T}{t_{1}}\right)\right]^{2}\right]\right\},
\end{gathered}
$$

where $S$ is a crack area. 


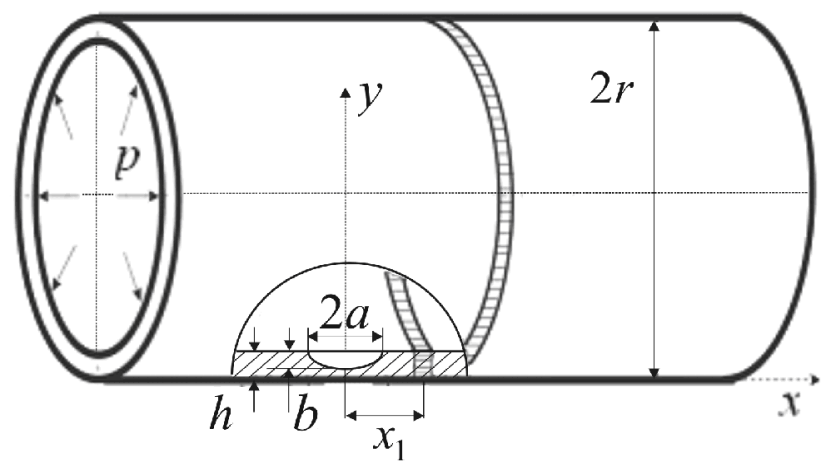

Fig. 5. Loading diagram of the pipe of steam pipe line with the crack near the weld joint

For simplification of computations while solving the task, an equivalent area method is to be used [11]. According to it, the change of the area of a moving crack of considered configuration is approximately similar to the semi-circular crack with a radius $\rho$ with the same initial area, and the speed of crack spread is steady in all its points. Then equation (11) will take the form as follows

$$
\begin{gathered}
\frac{d \rho}{d N}=\frac{\alpha_{0}(1-R)^{4}}{4 \sigma_{0 f} E\left(K_{f C}^{2}-K_{\operatorname{Imax}}^{2}(\rho)\right)}\left\{\left[K_{I \max }^{2}(\rho)+A_{2}\left[K_{\operatorname{Imax}}^{2}(\rho) K_{f C}^{-2}\right]^{m} \ln \left(\frac{t_{0}+T}{t_{1}}\right)\right]^{2}-\right. \\
\left.-\left[\left[K_{t h}^{2}+A_{2}\left[K_{t h}^{2} K_{f C}^{-2}\right]^{m} \ln \left(\frac{t_{0}+T}{t_{1}}\right)\right]^{2}\right]\right\} .
\end{gathered}
$$

Equation (12) determines only the kinetics of the growth of the creep-fatigue crack in the pipe wall. For determining the period of pre-critical crack growth, the initial and finite conditions should be added to equation (12)

$$
\begin{gathered}
N=0, \quad \rho(0)=\rho_{0}=\sqrt{a_{0} b_{0}} ; \\
N=N_{s}, \quad \rho\left(N_{s}\right)=h .
\end{gathered}
$$

Here, $N_{s}$ is a period of pre-critical crack growth in the pipe (residual resource of the steam pipeline); $a_{0}, b_{0}$ are the initial dimensions of semi-axes of the semi-elliptic crack.

Therefore, equation (12) together with initial and finite conditions (13), (14) is a computational model for the evaluation of the residual resource of the steam pipeline with semi-circular internal creepfatigue crack in the wall pipe near the ring weld joint.

In this case, on the basis of known results [11] the coefficient of the stress intensity $K_{\mathrm{I}}$ for the semicircular crack can be written as

$$
K_{\text {Imax }}=0.7 \sigma\left(x_{1}\right) \sqrt{\pi \rho}\left(1+0.32\left(\rho h^{-1}\right)^{2}\right) \cdot\left(1.04+0.23\left(\rho h^{-1}\right)^{2}-0,11\left(\rho h^{-1}\right)^{4}\right),
$$

where $\sigma\left(x_{1}\right)$ are total stresses appearing in the pipe wall are equal to the sum of residual stresses $\sigma_{3}\left(x_{1}\right)$ and stresses caused by external pressure $p$, that is

$$
\sigma\left(x_{1}\right)=\sigma_{3}\left(x_{1}\right)+p r h^{-1} .
$$

The values of residual stresses $\sigma_{3}\left(x_{1}\right)$ are determined on the basis of the results obtained in [12] as follows

$$
\begin{gathered}
\sigma_{3}\left(x_{1}\right)=0.5\left(\sigma_{3}^{(1)}+\sigma_{3}^{(2)}\right) \\
\sigma_{3}^{(1)}=\frac{48.13-2408.68 x_{1}}{1-109.53 x_{1}+3639 x_{1}^{2}}, \quad \sigma_{3}^{(2)}=\frac{34.01-1691 x_{1}}{1-108.02 x_{1}+3541 x_{1}^{2}} .
\end{gathered}
$$


Correlations (16)-(18) are substituted into (15). Then, for determining the period of pre-critical growth of the creep-fatigue crack in the wall of the steam pipeline near the weld joint, when the hermeticity of the pipe is broken, equation (12) is integrated under the conditions (13), (14). As a result, the following correlation is obtained

$$
\begin{aligned}
N_{s}= & \frac{4 \sigma_{o f} E}{\alpha_{0}(1-R)^{4}} \int_{\rho_{0}}^{h}\left\{\left[K_{\operatorname{Imax}}^{2}\left(\rho, x_{1}\right)+A_{2}\left[K_{\operatorname{Imax}}^{2}\left(\rho, x_{1}\right) / K_{f C}^{2}\right]^{m} \ln \left(\frac{t_{0}+T}{t_{1}}\right)\right]^{2}-\right. \\
& \left.-\left[K_{t h}^{2}+A_{2}\left[K_{t h}^{2} / K_{f C}^{2}\right]^{m} \ln \left(\frac{t_{0}+T}{t_{1}}\right)\right]^{2}\right\}^{-1} \cdot\left(K_{f C}^{2}-K_{\operatorname{Imax}}^{2}\left(\rho, x_{1}\right)\right) d \rho .
\end{aligned}
$$

Therefore, if the characteristics of the material $K_{f C}, K_{t h}, A_{1}, m, t_{1}$ are known, the period of precritical growth of the creep-fatigue cracks is determined by correlation (19). The values $K_{f C}, K_{t h}, A_{1}$, $m, t_{1}$ for the pipe material of the steam pipeline with the weld joint are determined experimentally. It is known that the least resistance to the spread of the creep-fatigue cracks is located in the zone of thermal influence, and pipe weld joint of the steam pipeline is fractured exactly in this zone. Calculations are performed for a certain pipeline (steel 321) with following mechanical characteristics and geometrical parameters [13]:

$$
\begin{gathered}
K_{f C}=100 \mathrm{MPa} \sqrt{\mathrm{m}}, K_{t h}=7.5 \mathrm{MPa} \sqrt{\mathrm{m}}, R=0, T=12 \mathrm{~h}, \alpha_{0}=1.24, \\
A_{1}=1.25 \cdot 10^{-5} \mathrm{~m} / \mathrm{h}, h=60 \mathrm{~mm}, m=0,85, t_{1}=0.0128 \mathrm{~h}, \sigma_{0 f}=450 \mathrm{MPa}, \\
E=1.9 \cdot 10^{5} \mathrm{MPa}, b_{0}=9 \mathrm{~mm}, r=162 \mathrm{~mm}, p=24.5 \mathrm{MPa}, a_{0}=16 \mathrm{~mm} .
\end{gathered}
$$

By substituting (20) to formula (19) the dependence of residual resource $N_{s}$ of the pipe of the pipeline with the weld joint on the distance $x_{1}$ from the crack centre to the axis of weld joint (Fig. 6).

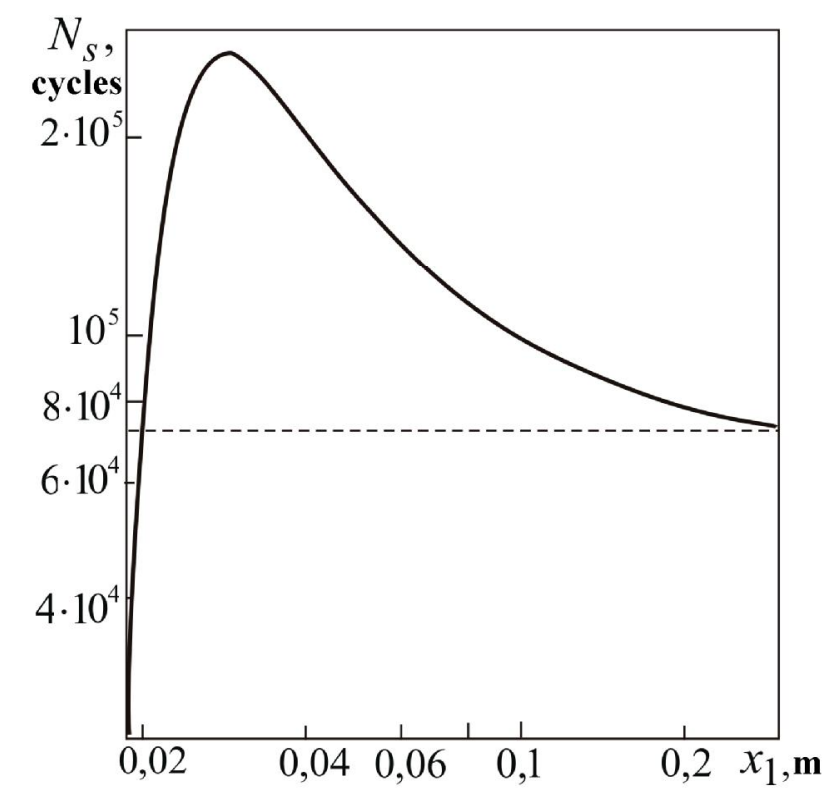

Fig. 6. Dependence of residual resource $N_{S}$ of the pipe of the pipeline with the weld joint on distance $x_{1}$ from the crack centre to the axis of weld joint 
Analyzing a curve depicted in Fig. 6 shows that residual stresses $\sigma_{3}\left(x_{1}\right)$ caused by weld joint influence the residual resource of the pipe with the weld joint ambiguously. At the same time, the calculation results (dotted line in Fig. 6) show that residual stresses at a distance of $x_{1} \approx 0,2 \mathrm{~m}$ do not practically influence the operating life of the pipe of the pipeline.

\section{Conclusions}

On the basis of the energy method in fracture mechanics the computational model for determining the period of pre-critical growth of the internal surface creep-fatigue crack in the pipe of the steam pipeline located near the weld joint in the area of residual stresses in the thermal influence zone. The residual resource of the pipe of the pipeline with weld joint at the distance from the crack centre to the axis of the weld joint has been evaluated.

\section{References}

[1] G. P. Karzov, V. P. Leonov, and B. T. Timofeev, Svarnye sosudy vysokogo davleniia: prochnost $i$ dolgovechnost [Welded vessels of high pressure: strength and durability]. Leningrad, Russia: Mashinostroenie Publ., 1982. [in Russian].

[2] V. I. Kyr'ian, V. A. Osadchuk, and M. M. Nykolyshyn, Mekhanika ruinuvannia zvarnykh z'iednan metalokonstruktsii [Mechanics of destruction of welded joints of metal structures]. Lviv, Ukraine: Spolom Publ., 2007. [in Ukrainian].

[3] G. P. Karzov, et al., "Vliianie ostatochnykh napriazhenii na traektoriiu i skorost rasprostraneniia treshchiny pri tciklicheskom nagruzhenii svarnykh soedinenii" ["Influence of residual stresses on a trajectory and speed of a crack propagation at cyclic loading of welded joints"], Avtomaticheskaia svarka [Automatic welding], no. 3, pp. 5-10, 1986. [in Russian].

[4] F. A. Khromchenko, Resurs svarnykh soedinenii paroprovodov [Resource of welded joints of steam pipelines]. Moscow, Russia: Mashinostroenie Publ., 2002. [in Russian].

[5] O. Ye. Andreikiv, R. M. Lesiv, and I. Ya. Dolinska, "Zalezhnist periodiv dokrytychnoho rostu povzuchovtomnoi trishchyny vid periodu tsyklu navantazhennia" ["Dependence of periods of subcritical growth of creepingfatigue crack on the loading cycle period"], Fizyko-khimichna mekhanika materialiv [Physical and chemical mechanics of materials], no. 4, pp. 31-38, 2009. [in Ukrainian].

[6] O. Ye. Andreikiv, I. Ya. Dolinska, and N. V. Yavorska "Otsinka periodiv zarodzhennia i poshyrennia povzucho-vtomnykh trishchyn v tonkostinnykh elementakh konstruktsii" ["Estimation of periods of origin and distribution of creeping-fatigue cracks in thin-walled elements of structures"], Fizyko-khimichna mekhanika materialiv [Physical and chemical mechanics of materials], no. 3, pp. 7-15, 2011. [in Ukrainian].

[7] V. I. Makhnenko, Resurs bezopasnoi ekspluatatcii svarnykh soedinenii i uzlov sovremennykh konstruktcii [Resource of safe operation of welded joints and units of modern structures]. Kyiv, Ukraine: Naukova dumka Publ., 2006. [in Russian].

[8] Y. Murakami, Stress intensity factors handbook. vols. 1-2, Oxford, UK: Pergamon Press, 1987.

[9] S. E. Kovchik, and E. M. Morozov, Kharakteristiki kratkovremennoi treshchinostoikosti materialov $i$ metody ikh opredeleniia [Characteristics of short-term crack resistance of materials and methods for their determination]. Kyiv, Ukraine: Naukova dumka Publ., 1988. [in Russian].

[10] Romaniv O. N., et al., Ustalost i tciklicheskaia treshchinostoikost konstruktcionnykh materialov [Fatigue and cyclic crack resistance of structural materials]. Kyiv, Ukraine: Naukova dumka Publ., 1990. [in Russian].

[11] O. Ye. Andreikiv, and N. B. Sas, "Vyznachennia zalyshkovoho resursu truby z poverkh $\neg$ nevoiu trishchynoiu pry dovhotryvalomu tysku i vysokii temperaturi" ["Determination of the residual life of a pipe with a superficial crack under long-term pressure and high temperature"], Mashynoznavstvo [Machines science], no. 4, pp. 3-6, 2005. [in Ukrainian].

[12] Yu. V. Banakhevych, O. Ye. Andreikiv, and M. B. Kit, "Vplyv roztashuvannia vidnosno zvarnoho shva poverkhnevoi trishchyny v stintsi truby na zalyshkovu dovhovichnist zvarnoho z'iednannia" ["The effect of the location of the weld on the surface cracks in the pipe wall on the residual durability of the welded joint"], Naukovyi visnyk IFNTUNH [Scientific Herald of Ivano-Frankivsk National Technical University of Oil and Gas], no. 2 (16), pp. 108-112, 2007. [in Ukrainian].

[13] D. N. Gladwin, et al., "Creep, fatigue and creep-fatigue crack growth rates in parent and simulated HAZ type 321 stainless steel," Fatigue and Fract. Eng. Mater. and Struct., vol. 11, no. 5, pp. 355-370, 1988. 